\title{
Nutritional assessment of omega-3 fatty acids intake in schizophrenia patients group
}

\author{
Ocena spożycia niezbędnych kwasów tłuszczowych omega-3 w grupie pacjentów \\ ze schizofrenią
}

Joanna $\operatorname{Rog}^{1}$ ABCDE https://orcid.org/0000-0003-4057-9507

Kaja Karakuła ${ }^{2}$ BEF https://orcid.org/0000-0003-1493-8502

Agnieszka Próchnicka ${ }^{3}$ BEF http://orcid.org/0000-0002-6033-7241

Hanna Karakula-Juchnowicz ${ }^{1}$ ACD https://orcid.org/0000-0002-5971-795X

\footnotetext{
${ }^{1}$ I Department of Psychiatry, Psychotherapy and Early Intervention, Medical University of Lublin, Poland

${ }^{2}$ Student Research Group at the I Department of Psychiatry, Psychotherapy and Early Intervention, Medical University of Lublin, Poland

${ }^{3}$ Institute of Pedagogy, Maria Curie Skłodowska University, Lublin, Poland
}

\begin{abstract}
Introduction: Schizophrenia is a chronic mental disease which significantly affects functioning and quality of life of patients. Lifestyle, including irregular eating habits, is a factor possibly intensifying symptoms of the disease and unwanted effects of pharmacotherapy. Due to positive effect on metabolic parameters demonstrated in numerous studies and participation in structure and functioning of central nervous system, omega-3 essential unsaturated fatty acids (EFAs) are the suggested form of schizophrenia cotheraphy.

Aim: The purpose of this paper was to evaluate EFAs (especially omega-3 family) consumption by individuals with schizophrenia and comparing contents of these acids in the diets of female and male patients.

Method: A study was conducted with the participation of 32 patients, recruited in the Psychiatric Outpatient Department of the Independent Public Clinical Hospital No. 1 in Lublin, with diagnosed schizophrenia. Data concerning the intake of EFAs was acquired in the course of 24-hour diet recall.

Results: Average intake of omega-3 EFAs in the examined population was $2.40 \pm 2.85 \mathrm{~g}$, of which only $201.6 \pm 501.5 \mathrm{mg}$ was constituted by EPA and DHA acids. The intake of omega-3 EFAs did not differ between men and women groups ( $p>0.05)$. Food rations of the $91 \%$ responders were characterised with the intake of EPA and DHA acids below the adequate intake level (AI). Conclusions: Patients suffering from schizophrenia consume insufficient amounts of EPA and DHA acids. Evidence suggests that optimum intake of omega-3 EFAs could bring significant benefits for this group of patients. People suffering from schizophrenia should be attended with the care of a dietician, who will choose optimum strategy for supplying sufficient amount of nutrients in the diet.
\end{abstract}

Keywords: schizophrenia, omega-3 essential unsaturated fatty acids, dietary assessment

\section{Streszczenie}

Wstęp: Schizofrenia jest przewlekłą chorobą psychiczną, która w znamienny sposób wpływa na funkcjonowanie i jakość życia. Styl życia, w tym nieprawidłowe zachowania żywieniowe, są czynnikami mogącymi nasilać objawy choroby oraz niepożądane skutki farmakoterapii. Ze względu na wykazany w licznych badaniach pozytywny wpływ na parametry metaboliczne oraz udział w strukturze i funkcjonowaniu mózgu, niezbędne nienasycone kwasy tłuszczowe (NNKT) omega-3 są proponowaną formą koterapii schizofrenii.

Cel pracy: Celem niniejszej pracy była ocena spożycia NNKT (ze szczególnym uwzględnieniem rodziny omega-3) przez pacjentów chorujących na schizofrenię oraz porównanie ich zawartości w diecie badanych kobiet i mężczyzn. 
Metoda: Przeprowadzono badanie z udziałem 32 pacjentów ze zdiagnozowaną schizofrenią, rekrutowanych z Poradni Psychiatrycznej Samodzielnego Szpitala Klinicznego nr 1 w Lublinie. Dane o spożyciu NNKT uzyskano metodą 24-godzinnego wywiadu.

Wyniki: Średnie spożycie NNKT omega-3 w badanej grupie wynosiło 2,40 2 2,85 g, z czego 201,6 \pm 501,5 mg stanowiły kwasy EPA i DHA. Spożycie NNKT omega-3 nie różniło się w grupach kobiet i mężczyzn (p>0.05). Racje pokarmowe 91\% badanych osób charakteryzowały się spożyciem kwasów EPA i DHA poniżej poziomu wystarczającego spożycia (AI).

Wnioski: Pacjenci ze schizofrenią spożywają niewystarczające ilości kwasów EPA i DHA. Dowody naukowe sugerują, iż optymalne spożycie NNKT omega-3 mogłoby przynieść znaczące korzyści dla tej grupy pacjentów. Osoby cierpiące na schizofrenię powinny zostać otoczone opieką dietetyka, który wybierze optymalną strategię dostarczenia odpowiedniej ilości składników odżywczych z dietą..

Słowa kluczowe: schizofrenia, niezbędne nienasycone kwasy tłuszczowe omega-3, ocena sposobu żywienia

\section{Introduction}

Schizophrenia is a chronic mental illness with a varied clinical image, of which essential is the disintegration of personality. Despite the enormous advancement of medical knowledge, also in the area of psychiatry, aetiology of the illness remains not fully recognised. It has been proven that genetics in about $80 \%$ cases predisposes the onset of the illness, what suggests a contribution of environmental determinants in the aetiology of schizophrenia [1]. A link between the occurrence of schizophrenia and T.gondi infection with in prenatal period, perinatal complications, and late age of patient's father was proved in numerous epidemiological studies. The risk of falling ill with schizophrenia also increases among people with a status of a refugee, ones using marijuana, and inhabiting urban environment [2].

Despite the fact that the percentage of population suffering from schizophrenia stands at less than 1\% [3], the experienced symptoms and sickness absenteeism make it an enormous economic and health-related challenge. The quality of life among the patients suffering from schizophrenia is lower, compared to the quality of life among the general population. This phenomenon is caused by the experience of symptoms, social exclusion and gradual functional decline [4]. Unsatisfactory state of health results also from irregular lifestyle including nutritional habits. Abnormal health-related behaviour among the patients with psychiatric disorders predisposes to the development of cardiovascular diseases, contributing to the shortening of life expectancy by 20 years in the case of men and 15 years in the case of women [5]. Ways of non-pharmacological rehabilitation, which would improve the quality of life, lessen the psychopathological symptoms and side effects of pharmacotherapy applied, are sought [6].

One of the suggested forms of therapy are essential unsaturated fatty acids (EFAs) from the omega-3 family: docosahexaenoic acid (DHA) and eicosapentaenoic acid (EPA). DHA and EPA are substances appearing naturally in food, their main sources are oily sea fish [7].
Numerous studies confirm the link between the state of nutrition with EFA and DHA acids and exacerbation of psychopathological symptoms of schizophrenia. Studies evaluating the effectiveness of supplementation with omega-3 EFAs with patients suffering from schizophrenia are, however, ambiguous [8]. Despite this, in 2006 there were published recommendations by the American Psychiatric Association regarding supplementation omega-3 EFAs in the population of psychiatric patients [9]. Inconsistencies of hitherto results indicate the necessity of seeking the predicators of positive response to cotherapy with omega-3 EFAs. One of the considered factors of favourable outcome is the consumption and the state of nutrition with omega-3 EFAs. Mellor et al. have proven that a positive response to EPA and DHA is only obtained in tested groups with low concentration of omega-3 EFAs in blood [10]. Assessment of nutritional habits concerning fatty acids seems essential before including supplementation. Besides not yet commercialised studies of omega-3 levels in blood, an assessment of eating habits based on a nutrition interview is a simple and noninvasive method determining their level. The information about patient's dietary pattern allow to assess the risk of potential nutritional deficiencies, including EPA and DHA [7].

\section{Aim}

The purpose of the paper was the assessment of EFAs (omega-3 and omega- 6 families) consumption by patients suffering from schizophrenia and comparing the consumption between female and male patients.

\section{Materials and methods}

A study with the participation of patients with diagnosed schizophrenia was conducted. The patients were recruited in the Psychiatric Outpatient Department of the Independent Public Clinical Hospital No. 1 in Lublin. The criterium of inclusion into the study was diagnosis of schizophrenia made on the basis of the International Statistical Classification of Diseases and Related Health 
Problems (ICD-10).

The study was conducted according to the criteria set by the Declaration of Helsinki, and the protocol was approved by the Ethics Committee of the Medical University of Lublin. After description of the study, a written informed consent was obtained from every subject.

An original questionnaire consisting of 25 questions regarding socio-demographic information, state of health and nutritional habits, was used to obtain the data. The information about nutrition was acquired with the use of a 24-hour dietary recall taking into consideration the day prior to the study. The consumption of EFAs was calculated using ESHA Food Processor software with the tables of nutritional value for food products and dishes [11]. The final results were presented in the form of an average, a median, a standard deviation and, for EPA and DHA, a percentage of studied population, whose consumption was below or over the value for meeting the standards on the level of the Adequate Intake (AI). For statistical calculations Statistica software, ver. 12, was used. The hypothesis about the importance of differences between groups of men and women was tested with t-student and Mann-Whitney U test on the significance level $\alpha=0.05$.

\section{Results}

\section{a. Socio-demographic data of the examined population}

Table 1. presents the characteristic of studied population. The number of 32 patients participated in the study - 14 (44\%) women and 18 (56\%) men with diagnosed schizophrenia according to ICD-10 diagnostic criteria. The average age in the studied group stood at 36 \pm 11 , for women $35 \pm 11$ and for men $37 \pm 11$. The average Body Mass Index (BMI) of respondents was $28.16 \pm 5.73$ $\mathrm{kg} / \mathrm{m} 2$, what equals to being overweight, for women 26.24 $\pm 6.80 \mathrm{~kg} / \mathrm{m} 2$ and for men $29.23 \pm 5.12 \mathrm{~kg} / \mathrm{m} 2$.

\section{b. Energetic value and macronutrients content in respondent's diets}

The average energetic value of food portions in the studied population stood at $1917.75 \pm 602.59$ kilocalories per day (kcal/d) (Table 2). In the group of women the consumption was $1762.75 \pm 511.86 \mathrm{kcal} / \mathrm{d}$ (Table 3), whereas in the group of men $2134.31 \pm 630.75 \mathrm{kcal} / \mathrm{d}$ (Table 4). The respondents consumed on average 252.57 \pm 82.84 g carbohydrates/d, $70.03 \pm 25.34$ g protein $/ \mathrm{d}$ and $82.53 \pm 31.34 \mathrm{~g}$ fat $/ \mathrm{d}$. Following the analysis of macroelements content in subgroup of men and women, it was evidenced that women consume on average 216.36 \pm 65.19 g carbohydrates/d, $64.81 \pm 29.06 \mathrm{~g}$ protein/d and $76.69 \pm 27.93 \mathrm{~g}$ fat $/ \mathrm{d}$, whereas men $280.74 \pm 85.69 \mathrm{~g}$ carbohydrates/d, $74.09 \pm 22.10 \mathrm{~g}$ protein/d and 87.07
Table 1. The characteristic of examined population

\begin{tabular}{|c|c|c|c|}
\hline Variable & Total & Women & Men \\
\hline Age & $36 \pm 11$ & $35 \pm 11$ & $37 \pm 11$ \\
\hline$B M I(\mathrm{~kg} / \mathrm{m} 2)$ & $28.16 \pm 5.73$ & $26.24 \pm 6.80$ & $29.23 \pm 5.12$ \\
\hline Variable & \multicolumn{3}{|l|}{$n(\%)$} \\
\hline Sex & & $14(44)$ & $18(56)$ \\
\hline \multicolumn{4}{|c|}{ Place of residence } \\
\hline Urban & $20(62.5)$ & $8(57)$ & $12(67)$ \\
\hline Rural & $12(37.5)$ & $6(43)$ & $6(33)$ \\
\hline \multicolumn{4}{|c|}{ Education degree } \\
\hline Higher & $13(40)$ & $7(50)$ & $6(33)$ \\
\hline Secondary & $9(28)$ & $3(21)$ & $6(33)$ \\
\hline Vocational & $6(19)$ & $3(21)$ & $3(17)$ \\
\hline Underway & $4(13)$ & $1(7)$ & $3(17)$ \\
\hline \multicolumn{4}{|l|}{ Livelihood } \\
\hline $\begin{array}{l}\text { Manual } \\
\text { labour }\end{array}$ & $8(25)$ & $1(7)$ & $7(39)$ \\
\hline $\begin{array}{l}\text { Knowledge } \\
\text { work }\end{array}$ & $2(6)$ & $1(7)$ & $1(6)$ \\
\hline Unemployed & $4(12,5)$ & $3(21)$ & $1(6)$ \\
\hline Benefit & $20(62,5)$ & $7(50)$ & $13(72)$ \\
\hline Pension & $2(6)$ & $1(7)$ & $1(6)$ \\
\hline $\begin{array}{l}\text { Dependent } \\
\text { on parents }\end{array}$ & $3(9)$ & $1(7)$ & $2(11)$ \\
\hline
\end{tabular}

$\pm 33.83 \mathrm{~g}$ fat $/ \mathrm{d}$. Women consumed significantly less carbohydrates compared to men $(\mathrm{p}=0.03)$. However, no difference in energetic value of diet and in consumption of protein and fats between the groups of men and women were evidenced $(\mathrm{p}>0.05)$. It is worth mentioning that no differences between examined groups may be a result of small sample size.

\section{c. Fat consumption}

Table 5. presents consumption of fat and particular fatty acids fractions among the respondents. In the conducted study the average consumption of polyunsaturated fatty acids (PUFA) stood at $13.69 \pm 7.19$ $\mathrm{g} / \mathrm{d}$. No differences in consumption of PUFA between men and women were evidenced ( $p>0.05$ ). The amount of PUFA in women's daily food rations was on average $12.80 \pm 6.79$ $\mathrm{g} / \mathrm{d}$ (Table 6), whereas in the group of men it stood at 14.38 $\pm 7.80 \mathrm{~g} / \mathrm{d}$ ) (Table 7).

Consumption of omega-3 EFAs among the respondents on average stood at $11.31 \pm 6.67 \mathrm{~g} / \mathrm{d}$ and did not depend on sex (p>0.05) (women: $11.03 \pm 6.15 \mathrm{~g} / \mathrm{d}$, men: $11.35 \pm 6.88 \mathrm{~g} / \mathrm{d}$ ). The interviewees consumed on average $11.15 \pm 6.38 \mathrm{~g} / \mathrm{d}$ of omega- 6 linoleic acid (LA). 
Table 2. Total energy and nutrients intake in the examined population

\begin{tabular}{|l|l|l|l|l|l|l|}
\hline Nutrient & Average intake & SD & $95 \%$ CI SD & V & Median \\
\hline Energy (kcal) & 1971.75 & 602.59 & $483.10-801.13$ & 30.56 & 1905.11 \\
\hline $\begin{array}{l}\text { Carbohydrates } \\
(g)\end{array}$ & 252.57 & 82.84 & $66.41-110.13$ & 32.80 & 242.86 & 0.45 \\
\hline Protein $(g)$ & 70.03 & 25.34 & $20.34-33.73$ & 36.23 & 65.98 & 0.07 \\
\hline Fat $(g)$ & 82.53 & 31.34 & $25.13-41.67$ & 37.97 & 78.63 \\
\hline
\end{tabular}

SD - standard deviation; 95\% CI - 95\% confidence interval; $V$ - coefficient of variation

Table 3. Total energy and nutrients intake in the women group

\begin{tabular}{|l|l|l|l|l|l|}
\hline Nutrient & Average intake & SD & $\mathbf{9 5 \% C I ~ S D}$ & V & Median \\
\hline Energy (kcal) & 1762.75 & 511.86 & $371.07-824.63$ & 29.04 & 1654.62 \\
\hline Carbohydrates $(g)$ & 216.36 & 65.19 & $47.26-105.03$ & 30.13 & 199.98 \\
\hline Protein $(g)$ & 64.81 & 29.06 & $21.07-46.82$ & 44.85 & 61.04 \\
\hline Fat $(g)$ & 76.69 & 27.93 & $20.25-45.00$ & 36.42 & 78.63 \\
\hline
\end{tabular}

SD - standard deviation; 95\% CI - 95\% confidence interval; V-coefficient of variation

Table 4. Total energy and nutrients intake in the men group

\begin{tabular}{|l|l|l|l|l|l|}
\hline Nutrient & Average intake & SD & $\mathbf{9 5 \% C I ~ S D}$ & V & Median \\
\hline Energy (kcal) & 2134.31 & 630.75 & $473.31-945.59$ & 29.55 & 2090.62 \\
\hline Carbohydrates $(g)$ & 280.74 & 85.69 & $64.30-128.47$ & 30.52 & 256.44 \\
\hline Protein $(g)$ & 74.09 & 22.10 & $16.58-33.12$ & 29.82 & 71.13 \\
\hline Fat $(g)$ & 87.07 & 33.83 & $25.38-50.72$ & 38.85 & 81.55 \\
\hline
\end{tabular}

SD - standard deviation; 95\% CI - 95\% confidence interval; V-coefficient of variation

Average content in food ration in the group of women was $10.83 \pm 6.18 \mathrm{~g} / \mathrm{d}$, whereas in the group of men $11.41 \pm 6.88$ $\mathrm{g} / \mathrm{d}$ ) and did not differ between the groups ( $\mathrm{p}>0.05$ ).

Also, no differences in consumption of omega-3 EFAs, ALA, EPA and DHA between the groups of men and women were observed ( $p>0.05$ ). Consumption of omega-3 EFAs among the respondents of both sexes was on average 2.4 $\pm 2.85 \mathrm{~g} / \mathrm{d}: \alpha$-linoleic acid (ALA) - $2.16 \pm 2.67 \mathrm{~g} / \mathrm{d}, \mathrm{EPA}-$ $84.7 \pm 256.4 \mathrm{mg} / \mathrm{d}$, DHA $-116.9 \pm 250.6 \mathrm{mg} / \mathrm{d}$. Interviewed women consumed on average $1.88 \pm 1.25 \mathrm{~g}$ of omega-3 EFAs/d: ALA - $1.67 \pm 0.95$ g/d, EPA - $57.1 \pm 205.2 \mathrm{mg} / \mathrm{d}$, DHA $100 \pm 225.3 \mathrm{mg} / \mathrm{d}$. Interviewed men consumed on average $2.53 \pm 3.47 \mathrm{~g}$ omega-3 EFAs/d: $2.53 \pm 3.47 \mathrm{~g} / \mathrm{d}$ ALA, $106.1 \pm 294.2 \mathrm{mg} / \mathrm{d}$ EPA, $130 \pm 274.4 \mathrm{mg} / \mathrm{d}$ DHA.

Average total consumption of EPA and DHA sum (EPA + DHA) among the respondents amounted to $201.6 \pm$ $501.5 \mathrm{mg} / \mathrm{d}$, what accounts for $80 \%$ of recommended daily intake on the level of AI: in the group of women was 157.1 $\pm 418.9 \mathrm{mg} / \mathrm{d}$, and in the group of men $236.1 \pm 567.1 \mathrm{mg} / \mathrm{d}$.

It was evidenced that food rations of $91 \%$ of respondents were characterised by consumption of EPA and DHA acids below the AI level. Only 2 men (6\%) and one woman (3\%) consumed EPA and DHA in the amount above AI (recommended amount).

\section{Discussion}

The Polish society consumes too little amounts of fish and seafood. According to data prepared by the Central Statistical Office, the average consumption of fish in 2015 stood at $12.5 \mathrm{~kg}$ of fish per person. By comparison. in the same year consumption of sugar amounted to the level of $40.5 \mathrm{~kg}$. and consumption of pork on the level of $41.4 \mathrm{~kg}$ [12]. Ensuring the optimum supply of omega-3 EFAs among people with mental disorders may contribute to improving the state of health in the patient's group. A positive effect of omega-3 EFAs on exacerbation of psychopathological symptoms, lipid management and functioning level of patients with schizophrenia was found [8]. Results of our research confirm that people suffering from schizophrenia do not supply in their diet recommended amount of omega-3 EFAs. Only 3 (9\%) respondents consumed EPA and DHA in the amount over AI level. Despite that, the average consumption of fat among the interviewed stood at high level $(82.53 \mathrm{~g} / \mathrm{d})$. 
Table 5. Fat intake in the examined population

\begin{tabular}{|c|c|c|c|c|c|c|}
\hline Nutrient & Average intake & $S D$ & $95 \% C I S D$ & $V$ & Median & $p$-value \\
\hline Fat $-\operatorname{total}(g)$ & 82.53 & 31.34 & $25.13-41.67$ & 37.97 & 78.63 & \\
\hline PUFA $(g)$ & 13.69 & 7.31 & $5.86-9.71$ & 53.37 & 10.97 & 0.41 \\
\hline Omega-3 EFAs $(g)$ & 2.40 & 2.85 & $2.28-3.79$ & 118.53 & 1.35 & 0.85 \\
\hline Omega-6 EFAs (g) & 11.31 & 6.47 & $5.19-8.61$ & 57.22 & 9.39 & 0.82 \\
\hline$L A(g)$ & 11.15 & 6.48 & $5.20-8.62$ & 58.14 & 9.08 & 0.66 \\
\hline$A L A(g)$ & 2.16 & 2.68 & $2.15-3.57$ & 124.42 & 1.31 & 0.92 \\
\hline$E P A(m g)$ & 84.7 & 256.4 & $206-341$ & 302.73 & 0 & 0.47 \\
\hline$D H A(m g)$ & 116.9 & 250.6 & $201-333$ & 214.39 & 20 & 0.49 \\
\hline$E P A+D H A(m g)$ & 201.6 & 501.5 & $402-667$ & 248.81 & 30 & 0.46 \\
\hline
\end{tabular}

SD - standard deviation; 95\% CI - 95\% confidence interval; V-coefficient of variation; $p$-value - statistical significance - women vs men. ${ }^{*} p<0.05$

Table 6. Fat intake in the women group

\begin{tabular}{|c|c|c|c|c|c|}
\hline Nutrient & Average intake & $S D$ & $95 \% C I S D$ & $\boldsymbol{V}$ & Median \\
\hline Fat - total $(g)$ & 76.69 & 27.93 & $20.25-45.00$ & 36.42 & 78.63 \\
\hline PUFA $(g)$ & 12.80 & 6.79 & $4.92-10.94$ & 53.06 & 11.09 \\
\hline Omega-3 EFAs (g) & 1.88 & 1.25 & $0.90-2.00$ & 66.71 & 1.33 \\
\hline Omega-6 EFAs (g) & 11.03 & 6.15 & $4.46-9.91$ & 55.77 & 9.17 \\
\hline$L A(g)$ & 10.83 & 6.18 & $4.48-9.95$ & 57.06 & 8.40 \\
\hline$A L A(g)$ & 1.67 & 0.95 & $0.69-1.54$ & 57.19 & 1.31 \\
\hline$E P A(m g)$ & 57.1 & 205.2 & $149-331$ & 359.13 & 0 \\
\hline$D H A(m g)$ & 100 & 225.3 & $163-363$ & 225.25 & 20 \\
\hline$E P A+D H A(m g)$ & 157.1 & 418.9 & $304-675$ & 266.54 & 20 \\
\hline
\end{tabular}

SD - standard deviation; 95\% CI - 95\% confidence interval; V-coefficient of variation

Table 7. Fat intake in the men group

\begin{tabular}{|c|c|c|c|c|c|}
\hline Nutrient & Average intake & $S D$ & $95 \% C I S D$ & $\boldsymbol{V}$ & Median \\
\hline Fat - total $(g)$ & 87.07 & 33.83 & $25.38-50.72$ & 38.85 & 81.55 \\
\hline PUFA $(g)$ & 14.38 & 7.80 & $5.86-11.70$ & 54.26 & 54.26 \\
\hline Omega-3 EFAs $(g)$ & 2.82 & 3.63 & $2.72-5.44$ & 128.81 & 1.39 \\
\hline Omega-6 EFAs (g) & 11.35 & 6.88 & $5.16-10.31$ & 59.68 & 9.39 \\
\hline$L A(g)$ & 11.41 & 6.88 & $5.16-10.31$ & 60.31 & 9.25 \\
\hline$A L A(g)$ & 2.53 & 3.47 & $2.61-5.21$ & 137.12 & 1.29 \\
\hline$E P A(m g)$ & 106.1 & 294.2 & $221-441$ & 277.24 & 0 \\
\hline$D H A(m g)$ & 130 & 274.4 & $206-411$ & 211.04 & 25 \\
\hline$E P A+D H A(m g)$ & 236.1 & 567.1 & $426-850$ & 240.14 & 40 \\
\hline
\end{tabular}

SD - standard deviation; 95\% CI - 95\% confidence interval; V-coefficient of variation 
In spite of the fact that energetic value was on average $1971.75 \mathrm{kcal} / \mathrm{d}$ among the respondents, there was observed a tendency for overweight and obesity (average value of BMI in the group of women was 26.24 $\mathrm{kg} / \mathrm{m} 2$, whereas in the group of men $29.23 \mathrm{~kg} / \mathrm{m} 2$ ). This fact may result from undervaluing the consumed amounts of products by the interviewees. Patient's cognitive disorders which may significantly affect the credibility of the conducted interview, as well as detrimental metabolic changes resulting from used pharmacological treatment. Bad nutritional choices increase the risk of being overweight and obese, and are the cause of metabolic complications [13].

Incorrect structure of consumption, including insufficient supply of omega-3 EFAs, may result from a number of disease-related factors. Patient's socioeconomic status (low income and high treatment costs) may influence the decisions regarding consumed food groups and their quality [14]. In the conducted study it has been evidenced that, despite the fact that $40 \%$ of respondents had higher education, as much as $62.5 \%$ drew benefits. Another predicator of improper diet are, observed in schizophrenia, advancing disorders of cognitive functions. Cognitive deficits increase the likeness of choosing products easy to prepare, characterised by high level of processing and low nutritional value [13]. Improper nutritional habits are also promoted by patient's lowered mood and motivation. They lead to passivity in various areas of life, including the care about its style. Finally, insufficient knowledge about nutrition, lack of awareness of crucial positive effect of nutritional elements on health may result in their inadequate consumption [8].

\section{Conclusions}

1. Conducted studies confirm that patients with schizophrenia supply in their diet insufficient amounts of omega-3 EFAs.

2. Nutritional deficiencies resulting from improper diet may exacerbate psychopathological symptoms of the disease.

3. Nutritional education of patients is necessary and that will enable to improve the state of nutrition, decreasing the risk of detrimental metabolic complications and better response to pharmacological treatment.

4. In the patients' groups, whose optimum consumption of omega-3 EFAs is impossible to obtain, it is necessary to consider and implement supplementation with EPA and DHA.

\section{Wstęp}

Schizofrenia jest przewlekłą choroba psychiczną o różnorodnym obrazie klinicznym, której istotą jest dezintegracja osobowości. Pomimo ogromnego postępu wiedzy medycznej, także w dziedzinie psychiatrii, etiologia choroby pozostaje nie do końca poznana. Wykazano, iż uwarunkowania genetyczne w około 80\% usposabiają do rozwinięcia się choroby, co wskazuje na udział determinantów środowiskowych w jej etiologii [1]. W licznych badaniach epidemiologicznych wykazano związek pomiędzy występowaniem schizofrenii a infekcją T.gondii w okresie prenatalnym, komplikacjami okołoporodowymi oraz późnym wiekiem ojca osób chorych. Ryzyko zachorowania na schizofrenię wzrasta także wśród osób posiadających statusu imigranta, stosujących marihuanę oraz zamieszkujących środowisko wielkomiejskie [2].

Pomimo, iż odsetek populacji cierpiącej na schizofrenię wynosi mniej niż 1\% [3], to doświadczane objawy oraz absencja chorobowa czynią z niej ogromne wyzwanie ekonomiczne i zdrowotne. Jakość życia pacjentów ze schizofrenią jest niższa, w porównaniu do jakości życia osób z populacji ogólnej. Zjawisko to spowodowane jest przez doświadczane objawy chorobowe, wykluczenie społeczne oraz stopniową utratą sprawności [4]. Niezadowalający stan zdrowia wynika także $\mathrm{z}$ niewłaściwego stylu życia, w tym wzorców żywieniowych. Nieprawidłowe zachowania zdrowotne pacjentów z zaburzeniami psychicznymi predysponują do rozwoju chorób sercowo-naczyniowych, przyczyniając się do skrócenia oczekiwanej długości życia o 20 lat w przypadku mężczyzn i 15 lat w przypadku kobiet [5]. Poszukiwane są formy oddziaływań niefarmakologicznych, które poprawią jakość życia, zmniejszą nasilenie objawów psychopatologicznych oraz skutków ubocznych stosowanej farmakoterapii [6].

Jedną z proponowanych form terapii są niezbędne nienasycone kwasy tłuszczowe (NNKT) z rodziny omega-3: kwas dokozaheksaenowy (DHA) oraz eikozapentaenowy (EPA). DHA i EPA są substancjami naturalnie występującymi w żywności, główne źródła to tłuste ryby morskie [7]. Liczne badania potwierdzają związek pomiędzy stanem odżywienia kwasami EPA i DHA a nasileniem objawów psychopatologicznych w schizofrenii. Badania oceniające skuteczność suplementacji kwasów NNKT omega-3 u pacjentów ze schizofrenią są natomiast niejed noznaczne [8]. Pomimo to, w 2006 roku ukazały się rekomendacje Amerykańskiego Towarzystwa Psychiatrycznego dotyczące suplementacji NNKT omega-3 w populacji pacjentów psychiatrycznych [9]. Niespójność dotychczasowych wyników wskazuje na konieczność poszukiwań wyznaczników pozytywnej odpowiedzi na koterapię NNKT omega-3. Jednym z rozważanych czynników, decydujących o skuteczności 
suplementacji kwasami tłuszczowymi, jest spożycie i stan odżywienia NNKT omega-3. Mellor i wsp. dowiedli, że pozytywną odpowiedź na EPA i DHA uzyskuje się wyłącznie w grupach badanych z niskim stężeniem NNKT omega-3 we krwi [10]. Ocena stanu odżywienia kwasami tłuszczowymi wydaje się kluczowa przed włączeniem suplementacji. Poza nieskomercionalizowanymi jeszcze badaniami poziomów omega-3 we krwi, prostą i nieinwazyjną metodą określającą go jest ocena sposobu żywienia oparta na wywiadzie żywieniowym [7]. Pozyskanie informacji o zwyczajowej diecie pacjenta pozwala na ocenę ryzyka potencjalnych niedoborów żywieniowych, w tym także kwasów EPA i DHA.

\section{Cel}

Celem pracy była ocena spożycia NNKT (z rodzin omega-3 oraz omega-6) przez pacjentów cierpiących na schizofrenię oraz porównanie spożycia pomiędzy badanymi kobietami i mężczyznami.

\section{Materiał i metody}

Przeprowadzono badanie $\mathrm{z}$ udziałem pacjentów ze zdiagnozowaną schizofrenią. Pacjenci rekrutowani byli z Poradni Psychiatrycznej Samodzielnego Szpitala Klinicznego nr 1 w Lublinie. Kryterium włączenia do badania była diagnoza, postawiona $\mathrm{w}$ oparciu o Międzynarodową Klasyfikacja Chorób ICD-10.

Badanie przeprowadzono zgodnie z kryteriami określonymi w Deklaracji Helsińskiej, a protokół został zatwierdzony przez Komisję Bioetyczną Uniwersytetu Medycznego w Lublinie. Po opisaniu badania, od każdego respondenta, uzyskano pisemną świadomą zgodę.

Do zebrania danych wykorzystano autorski kwestionariusz składający się z 25 pytań dotyczących danych socjodemograficznych, stanu zdrowia oraz nawyków żywieniowych. Dane o spożyciu uzyskano posługując się metodą 24-godzinnego wywiadu uwzględniając dzień poprzedzający badanie. Spożycie NNKT obliczono przy użyciu programu komputerowego ESHA Food Processor z wykorzystaniem Tabel wartości odżywczej produktów spożywczych i potraw [11]. Wyniki końcowe przedstawiono w postaci średniej, mediany, odchylenia standardowego oraz, dla kwasu eikozapentaenowego (EPA) i dokozaheksaenowego (DHA), procentu badanej populacji, których spożycie było poniżej lub powyżej wartości pokrycia normy na poziomie wystarczającego spożycia AI (ang. Adequate Intake). Do obliczeń statystycznych wykorzystano program Statistica, wersja 12. Hipotezę o istotności różnic między spożyciem w grupach kobiet i mężczyzn testowano testami t-studenta oraz U Manna-Whitneya na poziomie istotności $\alpha=0,05$.

\section{Wyniki}

\section{a. Dane socjodemograficzne badanej populacji}

Tabela 1 przedstawia charakterystykę badanej populacji. W badaniu uczestniczyło 32 pacjentów - 14 (44\%) kobiet oraz 18 (56\%) mężczyzn, ze zdiagnozowaną schizofrenią według kryteriów diagnostycznych ICD10. Średnia wieku $\mathrm{w}$ badanej grupie wynosiła $36 \pm 11$ lat, dla kobiet $35 \pm 11$ lat, natomiast dla mężczyzn 37 lat \pm 11 lat. Średnia wartość wskaźnika masy ciała (BMI) ankietowanych wynosiła 28,16 $\pm 5,73 \mathrm{~kg} / \mathrm{m} 2$, co odpowiada nadwadze, dla kobiet $26,24 \pm 6,80 \mathrm{~kg} / \mathrm{m} 2$, natomiast dla mężczyzn 29,23 $\pm 5,12 \mathrm{~kg} / \mathrm{m} 2$,

Tabela 1. Charakterystyka socjodemograficzna badanej populacji

\begin{tabular}{|l|l|l|l|}
\hline Zmienna & Ogółem & Kobiety & Mężczyźni \\
\hline Wiek & $36 \pm 11$ & $35 \pm 11$ & $37 \pm 11$ \\
\hline BMI $(\mathrm{kg} / \mathrm{m} 2)$ & $28,16 \pm 5,73$ & $26,24 \pm 6,80$ & $29,23 \pm 5,12$ \\
\hline Zmienna & $\boldsymbol{n}(\%)$ & $14(44)$ & $18(56)$ \\
\hline Płeć & \multicolumn{5}{|l}{} \\
\hline Miejsce zamieszkania & $20(62,5)$ & $8(57)$ & $12(67)$ \\
\hline Miasto & $12(37,5)$ & $6(43)$ & $6(33)$ \\
\hline Wieś & &
\end{tabular}

Wykształcenie

\begin{tabular}{|l|l|l|l|}
\hline Wyższe & $13(40)$ & $7(50)$ & $6(33)$ \\
\hline Średnie & $9(28)$ & $3(21)$ & $6(33)$ \\
\hline Zawodowe & $6(19)$ & $3(21)$ & $3(17)$ \\
\hline $\begin{array}{l}\text { W trakcie } \\
\text { edukacji }\end{array}$ & $4(13)$ & $1(7)$ & $3(17)$ \\
\hline
\end{tabular}

Źródło utrzymania

\begin{tabular}{|l|l|l|l|}
\hline $\begin{array}{l}\text { Praca } \\
\text { fizyczna }\end{array}$ & $8(25)$ & $1(7)$ & $7(39)$ \\
\hline $\begin{array}{l}\text { Praca } \\
\text { umysłowa }\end{array}$ & $2(6)$ & $1(7)$ & $1(6)$ \\
\hline Bezrobotny/a & $4(12,5)$ & $3(21)$ & $1(6)$ \\
\hline Renta/zasitek & $20(62,5)$ & $7(50)$ & $13(72)$ \\
\hline Emerytura & $2(6)$ & $1(7)$ & $1(6)$ \\
\hline $\begin{array}{l}\text { Na } \\
\text { utrzymaniu } \\
\text { rodziców }\end{array}$ & $3(9)$ & $1(7)$ & $2(11)$ \\
\hline
\end{tabular}

\section{b. Wartość energetyczna oraz udział makroskładników} w dietach ankietowanych

Średnia wartość energetyczna racji pokarmowych badanej populacji wynosiła 1917,75 \pm 602,59 kilokalorii na dobę (kcal/d) (Tabela 2). W grupie kobiet spożycie wynosiło $1762,75 \pm 511,86 \mathrm{kcal} / \mathrm{d}$ (Tabela 3 ), natomiast w grupie mężczyzn 2134,31 $\pm 630,75 \mathrm{kcal} / \mathrm{d}$ (Tabela 4). Osoby ankietowane spożywały średnio 252,57 \pm 
82,84 g węglowodanów/d, 70,03 $\pm 25,34$ g białka/d oraz $82,53 \pm 31,34 \mathrm{~g}$ tłuszczu/d. Po analizie zawartości makroskładników w podgrupach kobiet i mężczyzn, wykazano, iż kobiety spożywają średnio 216,36 \pm 65,19 g węglowodanów/d, 64,81 \pm 29,06 g białka/d oraz 76,69 $\pm 27,93 \mathrm{~g}$ tłuszczu/d, natomiast mężczyźni 280,74 \pm 85,69 g węglowodanów/d, 74,09 $\pm 22,10$ g białka/d oraz 87,07 \pm
33,83 g tłuszczów/d. Kobiety spożywały znamiennie mniej węglowodanów w porównaniu z mężczyznami $(p=0,03)$. Nie wykazano natomiast różnic w wartości energetycznej diety oraz spożyciu białka i tłuszczy między grupą kobiet i mężczyzn ( $p>0,05)$. Należy jednak podkreślić, że brak różnic w ocenianych zmiennych spowodowany może być małą liczebnością badanej grupy.

Tabela 2. Wartość energetyczna i zawartość makroskładników w dietach badanych

\begin{tabular}{|l|l|l|l|l|l|l|}
\hline Składnik & $\begin{array}{l}\text { Średnie } \\
\text { spożycie }\end{array}$ & $\mathbf{S D}$ & $\mathbf{9 5 \% C I ~ S D}$ & $\boldsymbol{V}$ & Mediana & p-value \\
\hline Energia (kcal) & 1971,75 & 602,59 & $483,10-801,13$ & 30,56 & 1905,11 & 0,45 \\
\hline Weglowodany $(g)$ & 252,57 & 82,84 & $66,41-110,13$ & 32,80 & 242,86 & $0,03^{*}$ \\
\hline Białko (g) & 70,03 & 25,34 & $20,34-33,73$ & 36,23 & 65,98 & 0,07 \\
\hline Tłuszcz (g) & 82,53 & 31,34 & $25,13-41,67$ & 37,97 & 78,63 & 0,36 \\
\hline
\end{tabular}

SD - odchylenie standardowe; 95\% CI - 95\% przedział ufności; $V$ - współczynnik zmienności; p-value - istotność statystyczna - kobiety vs mężczyźni, ${ }^{*} p<0.05$

Tabela 3. Wartość energetyczna i zawartość makroskładników w dietach badanych kobiet

\begin{tabular}{|l|l|l|l|l|l|}
\hline Składnik & Średnie spożycie & SD & $\mathbf{9 5 \% C I ~ S D}$ & $\boldsymbol{V}$ & Mediana \\
\hline Energia (kcal) & 1762,75 & 511,86 & $371,07-824,63$ & 29,04 & 1654,62 \\
\hline Węglowodany $(g)^{*}$ & 216,36 & 65,19 & $47,26-105,03$ & 30,13 & 199,98 \\
\hline Białko (g) & 64,81 & 29,06 & $21,07-46,82$ & 44,85 & 61,04 \\
\hline Tłuszcze (g) & 76,69 & 27,93 & $20,25-45,00$ & 36,42 & 78,63 \\
\hline
\end{tabular}

SD - odchylenie standardowe; 95\% CI - 95\% przedział ufności; $V$ - współczynnik zmienności; p-value - istotność statystyczna - kobiety vs mężczyźni, *p<0.05

Tabela 4. Wartość energetyczna i zawartość makroskładników w dietach badanych mężczyzn

\begin{tabular}{|l|l|l|l|l|l|}
\hline Składnik & Średnie spożycie & SD & $\mathbf{9 5 \% C I ~ S D}$ & V & Mediana \\
\hline Energia (kcal) & 2134,31 & 630,75 & $473,31-945,59$ & 29,55 & 2090,62 \\
\hline Węglowodany $(g)^{*}$ & 280,74 & 85,69 & $64,30-128,47$ & 30,52 & 256,44 \\
\hline Białko (g) & 74,09 & 22,10 & $16,58-33,12$ & 29,82 & 71,13 \\
\hline Tłuszcze $(g)$ & 87,07 & 33,83 & $25,38-50,72$ & 38,85 & 81,55 \\
\hline
\end{tabular}

SD - odchylenie standardowe; 95\% CI - 95\% przedział ufności; $V$ - współczynnik zmienności; p-value - istotność statystyczna - kobiety vs mężczyźni, * $p<0.05$

\section{c. Spożycie tłuszczu w badanej populacji}

Tabela 5. przedstawia spożycie tłuszczu oraz poszczególnych frakcji kwasów tłuszczowych wśród ankietowanych. W przeprowadzonym badaniu średnie spożycie wielonienasyconych kwasów tłuszczowych (WNKT) wynosiło 13,69 \pm 7,19 g/d. Nie wykazano różnic w spożyciu WNKT pomiędzy kobietami i mężczyznami ( $p>0,05)$. Ilość WNKT w dziennych racjach pokarmowych ankietowanych kobiet wynosiła średnio $12,80 \pm 6,79 \mathrm{~g} / \mathrm{d}$ (Tabela 6), natomiast w grupie mężczyzn 14,38 \pm 7,80 g/d) (Tabela 7).

Spożycie NNKT omega- 6 wśród badanych wynosiło średnio $11,31 \pm 6,67 \mathrm{~g} / \mathrm{d}$ i nie było zależne od płci $(\mathrm{p}>0,05)$ (kobiety: 11,03 \pm 6,15 g/d, mężczyźni: 11,35 \pm 6,88 g/d). Ankietowani spożywali średnio 11,15 $\pm 6,38 \mathrm{~g} / \mathrm{d}$ kwasu linolowego omega-6 (LA). Średnia zawartość LA w racji pokarmowej w grupie kobiet wynosiła 10,83 $\pm 6,18 \mathrm{~g} / \mathrm{d}$, natomiast $w$ grupie mężczyzn 11,41 $\pm 6,88 \mathrm{~g} / \mathrm{d}$ ) i nie różniła się między grupami ( $\mathrm{p}>0,05)$.

Nie obserwowano również różnic w spożyciu NNKT omega-3, ALA, EPA i DHA między kobietami i mężczyznami $(p>0,05)$. Spożycie NNKT omega-3 wśród badanych obydwu płci wynosiło średnio $2,4 \pm 2,85 \mathrm{~g} / \mathrm{d}$ : kwasu $\alpha$-linolenowego (ALA) - 2,16 $\pm 2,67 \mathrm{~g} / \mathrm{d}$, EPA - 84,7 \pm $256,4 \mathrm{mg} / \mathrm{d}$, DHA $-116,9 \pm 250,6 \mathrm{~g} / \mathrm{d}$. Ankietowane kobiety spożywały średnio 1,88 $\pm 1,25$ g NNKT omega-3/d: ALA - 
$1,67 \pm 0,95 \mathrm{~g} / \mathrm{d}, \mathrm{EPA}-57,1 \pm 205,2 \mathrm{mg} / \mathrm{d}$, DHA $100 \pm 225,3$ g/d. Ankietowani mężczyźni spożywali średnio 2,53 \pm 3,47 g NNKT omega-3/d: 2,53 $\pm 3,47$ g/d ALA, 106,1 \pm 294,2 mg/d EPA, 130 $\pm 274,4$ g/d DHA.

Średnie, łączne spożycie sumy EPA i DHA (EPA + DHA) wśród ankietowanych kształtowało się na poziomie $201,6 \pm 501,5 \mathrm{mg} / \mathrm{d}$, co stanowi $80 \%$ dziennego zalecanego spożycia na poziomie AI: w grupie kobiet wynosiło 157,1 \pm $418,9 \mathrm{mg} / \mathrm{d}$, a w grupie mężczyzn 236,1 $\pm 567,1 \mathrm{mg} / \mathrm{d}$.

Wykazano, iż racje pokarmowe $91 \%$ badanych osób charakteryzowały się spożyciem kwasów EPA i DHA poniżej poziomu AI. Wyłącznie 2 mężczyzn (6\%) oraz 1 kobieta (3\%) spożywało EPA i DHA w ilości powyżej poziomu AI (ilości rekomendowanej).

Tabela 5. Spożycie tłuszczu w badanej populacji

\begin{tabular}{|c|c|c|c|c|c|c|}
\hline Składnik & $\begin{array}{l}\text { Średnie } \\
\text { spożycie }\end{array}$ & $S D$ & $95 \% C I S D$ & V & Mediana & p-value \\
\hline Tłuszcze ogółem (g) & 82,53 & 31,34 & $25,13-41,67$ & 37,97 & 78,63 & \\
\hline$W N K T(g)$ & 13,69 & 7,31 & $5,86-9,71$ & 53,37 & 10,97 & 0,41 \\
\hline NNKT omega-3 $(g)$ & 2,40 & 2,85 & $2,28-3,79$ & 118,53 & 1,35 & 0,85 \\
\hline NNKT omega-6 $(g)$ & 11,31 & 6,47 & $5,19-8,61$ & 57,22 & 9,39 & 0,82 \\
\hline$L A(g)$ & 11,15 & 6,48 & $5,20-8,62$ & 58,14 & 9,08 & 0,66 \\
\hline$A L A(g)$ & 2,16 & 2,68 & $2,15-3,57$ & 124,42 & 1,31 & 0,92 \\
\hline$E P A(m g)$ & 84,7 & 256,4 & $206-341$ & 302,73 & 0 & 0,47 \\
\hline DHA (mg) & 116,9 & 250,6 & $201-333$ & 214,39 & 20 & 0,49 \\
\hline$E P A+D H A(m g)$ & 201,6 & 501,5 & $402-667$ & 248,81 & 30 & 0,46 \\
\hline
\end{tabular}

SD - odchylenie standardowe; 95\% CI - 95\% przedział ufności; $V$ - współczynnik zmienności; $p$-value - istotność statystyczna - kobiety vs mężczyźni, ${ }^{*} p<0.05$

Tabela 6. Spożycie tłuszczu w badanej populacji - kobiety

\begin{tabular}{|c|c|c|c|c|c|}
\hline Składnik & Średnie spożycie & $S D$ & $95 \% C I S D$ & $V$ & Mediana \\
\hline Tłuszcze ogółem (g) & 76,69 & 27,93 & $20,25-45,00$ & 36,42 & 78,63 \\
\hline$W N K T(g)$ & 12,80 & 6,79 & $4,92-10,94$ & 53,06 & 11,09 \\
\hline NNKT omega-3 $(g)$ & 1,88 & 1,25 & $0,90-2,00$ & 66,71 & 1,33 \\
\hline NNKT omega-6 $(g)$ & 11,03 & 6,15 & $4,46-9,91$ & 55,77 & 9,17 \\
\hline$L A(g)$ & 10,83 & 6,18 & $4,48-9,95$ & 57,06 & 8,40 \\
\hline$A L A(g)$ & 1,67 & 0,95 & $0,69-1,54$ & 57,19 & 1,31 \\
\hline$E P A(m g)$ & 57,1 & 205,2 & $149-331$ & 359,13 & 0 \\
\hline$D H A(m g)$ & 100 & 225,3 & $163-363$ & 225,25 & 20 \\
\hline$E P A+D H A(m g)$ & 157,1 & 418,9 & $304-675$ & 266,54 & 20 \\
\hline
\end{tabular}

SD - odchylenie standardowe; 95\% CI - 95\% przedział ufności; V - współczynnik zmienności

\section{Dyskusja}

Społeczeństwo polskie spożywa zbyt małe ilości ryb oraz owoców morza. Według opracowanych przez Główny Urząd Statystyczny danych przeciętne spożycie w roku 2015 stanowiło 12,5 kg ryb na 1 osobę. Dla porównania, w tym samym roku, spożycie cukru kształtowało się na poziomie $40,5 \mathrm{~kg}$, a spożycie wieprzowiny na poziomie $41,4 \mathrm{~kg}$ [12]. Zapewnienie optymalnej podaży NNKT omega-3 u osób z zaburzeniami psychicznymi może przyczynić się do poprawy stanu zdrowia wśród chorych. Wykazano pozytywny wpływ NNKT omega-3 na nasilenie objawów psychopatologicznych, gospodarkę lipidową oraz poziom funkcjonowania pacjentów ze schizofrenią [8]. Wyniki badań własnych, potwierdziły, iż osoby cierpiące na schizofrenię nie dostarczają z dietą zalecanej ilości NNKT omega-3. Wyłącznie 3 (9\%) respondentów spożywało EPA i DHA w ilości powyżej poziomu AI, mimo iż średnie spożycie tłuszczu wśród ankietowanych kształtowało się na wysokim poziomie $(82,53 \mathrm{~g} / \mathrm{d})$.

Wartość energetyczna diet wynosiła średnio 1971,75 $\mathrm{kcal} / \mathrm{d}$, jednak wśród badanych obserwowano tendencję do nadwagi i otyłości (średnia wartość wskaźnika BMI 
Tabela 7. Spożycie tłuszczu w badanej populacji - mężczyźni

\begin{tabular}{|c|c|c|c|c|c|}
\hline Składnik & Średnie spożycie & $S D$ & $95 \% C I S D$ & $V$ & Mediana \\
\hline Tłuszcze ogółem (g) & 87,07 & 33,83 & $25,38-50,72$ & 38,85 & 81,55 \\
\hline$W N K T(g)$ & 14,38 & 7,80 & $5,86-11,70$ & 54,26 & 54,26 \\
\hline NNKT omega-3 $(g)$ & 2,82 & 3,63 & $2,72-5,44$ & 128,81 & 1,39 \\
\hline NNKT omega-6 $(\mathrm{g})$ & 11,35 & 6,88 & $5,16-10,31$ & 59,68 & 9,39 \\
\hline$L A(g)$ & 11,41 & 6,88 & $5,16-10,31$ & 60,31 & 9,25 \\
\hline$A L A(g)$ & 2,53 & 3,47 & $2,61-5,21$ & 137,12 & 1,29 \\
\hline$E P A(m g)$ & 106,1 & 294,2 & $221-441$ & 277,24 & 0 \\
\hline$D H A(m g)$ & 130 & 274,4 & $206-411$ & 211,04 & 25 \\
\hline$E P A+D H A(m g)$ & 236,1 & 567,1 & $426-850$ & 240,14 & 40 \\
\hline
\end{tabular}

SD - odchylenie standardowe; 95\% CI - 95\% przedział ufności; $V$ - współczynnik zmienności

w grupie kobiet wynosiła $26,24 \mathrm{~kg} / \mathrm{m} 2$, natomiast w grupie mężczyzn 29,23 kg/m2). Fakt ten wynikać może z niedoszacowania ilości spożywanych przez osoby ankietowane produktów, zaburzeń funkcji poznawczych pacjentów, które w znamienny sposób wpłynąć mogą na wiarygodność przeprowadzanego wywiadu, jak również niekorzystnych zmian metabolicznych wynikających ze stosowanej farmakoterapii. Złe wybory żywieniowe pacjentów zwiększają ryzyko nadwagi i otyłości i są przyczyną powikłań metabolicznych [13].

Nieprawidłowa struktura spożycia, w tym zbyt niska podaż NNKT omega-3, wynikać może z szeregu różnych, związanych $\mathrm{z}$ chorobą czynników. Status socjoekonomiczny pacjentów (niskie dochody oraz wysokie koszty leczenia) wpływać mogą na decyzje dotyczące spożywanych grup produktów i ich jakości [14]. W przeprowadzonym badaniu wykazano, iż pomimo $40 \%$ ankietowanych pacjentów posiadało wykształcenie wyższe, aż $62,5 \%$ pozostawało na rencie bądź zasiłku. Kolejnym predykatorem złej diety są, obserwowane $\mathrm{w}$ schizofrenii, postępujące zaburzenia funkcji kognitywnych. Deficyty poznawcze zwiększają prawdopodobieństwo wyboru łatwych w przygotowaniu, charakteryzujących się wysokim stopniem przetworzenia oraz niską wartością odżywczą produktów [13]. Nieprawidłowym nawykom żywieniowym sprzyjają także obniżony nastrój i niski poziom motywacji pacjentów. Prowadzą one do bierności w różnych sferach życia, w tym dbałości o jego styl. Wreszcie, niedostateczna wiedza żywieniowa, brak świadomości dotyczącej istotności i pozytywnego oddziaływania składników odżywczych na zdrowie, skutkować mogą ich niedostatecznym spożyciem [8].

\section{Wnioski}

1. Przeprowadzone badanie potwierdza, iż pacjenci ze schizofrenią dostarczają z dietą niedostateczne ilość
NNKT omega-3.

2. Niedobory żywieniowe, będące skutkiem nieprawidłowej diety, mogą nasilać objawy psychopatologiczne choroby.

3. Konieczna jest edukacja żywieniowa pacjentów, która pozwoli na poprawę stanu odżywienia, zmniejszenie ryzyka niekorzystnych powikłań metabolicznych oraz lepszą odpowiedź na leczenie farmakologiczne.

4. W grupach pacjentów, u których optymalne spożycie NNKT omega-3 nie może być osiągnięte, konieczne jest rozważenie oraz włączenie suplementacji kwasów EPA i DHA.

\section{Conflict of interest}

The authors have declared no conflict of interest.

\section{References:}

1. Matheson SL, Shepherd AM, Laurens KR, Carr VJ. A systematic meta-review grading the evidence for non-genetic risk factors and putative antecedents of schizophrenia. Schizophrenia research. 2011;133:133-42.

2. Torrey EF, Bartko JJ, Yolken RH. Toxoplasma gondii and other risk factors for schizophrenia: an update. Schizophrenia bulletin. 2012;38:642-7.

3. Simeone JC, Ward AJ, Rotella P, Collins J, Windisch R. An evaluation of variation in published estimates of schizophrenia prevalence from 1990- 2013: a systematic literature review. BMC psychiatry. 2015;15:193.

4. Rajji TK, Miranda D, Mulsant BH. Cognition, function, and disability in patients with schizophrenia: a review of longitudinal studies. The Canadian Journal of Psychiatry. 2014;59:13-7.

5. Thornicroft G. Physical health disparities and mental illness: the scandal of premature mortality. The British Journal of Psychiatry. 2011;199:441-2.

6. Hjorth P, Medici CR, Juel A, Madsen NJ, Vandborg K, Munk-Jørgensen P. Improving quality of life and physical health in patients with schizophrenia: A 30-month program carried out in a real-life setting. International Journal of Social Psychiatry. 2017;63:287-96. 
7. Róg J, Karakuła-Juchnowicz H. Omega - 3 fatty acids in schizophrenia - part I: importance in the pathophysiology of schizophrenia. Current Problems of Psychiatry. 2016;17:198213.

8. Bozzatello P, Brignolo E, De Grandi E, Bellino S. Supplementation with Omega-3 Fatty Acids in Psychiatric Disorders: A Review of Literature Data. Journal of Clinical Medicine. 2016;5:67.

9. Freeman MP, Hibbeln JR, Wisner KL et al. Omega-3 Fatty Acids: Evidence Basis for Treatment and Future Research in Psychiatry. Fatty Acids. 67 (12): 1954-1967.

10. Mellor JE, Laugharne JDE, Peet M. Omega-3 fatty acid supplementation in schizophrenic patients. Human Psychopharmacology: Clinical and Experimental. 1996;11:3946.

11. Kunachowicz H, Nadolna I, Przygoda B, Iwanow K. Tabele wartości odżywczej produktów spożywczych. IŻŻ, Warszawa. 1998;434.

12. GUS. Rocznik Statystyczny Rolnictwa 2016. stat.gov. pl. https://stat.gov.pl/obszary-tematyczne/rocznikistatystyczne/roczniki-statystyczne/rocznik-statystycznyrolnictwa-2016,6,10.html. Accessed 9 Jul 2019.

13. Dipasquale S, Pariante CM, Dazzan P, Aguglia E, McGuire P,
Mondelli V. The dietary pattern of patients with schizophrenia: a systematic review. Journal of psychiatric research. 2013;47:197207.

14. Teasdale S, Samaras K, Wade T, Jarman R, Ward P. A review of the nutritional challenges experienced by people living with severe mental illness: a role for dietitians in addressing physical health gaps. Journal of human nutrition and dietetics. 2017;30:545-53.

\section{Corresponding author}

\section{Joanna Rog}

I Department of Psychiatry, Psychotherapy and Early Intervention,

Medical University of Lublin, Poland, Głuska 1 Street, 20-439 Lublin, mail: joannarog@umlub.pl

Otrzymano: 18.07.2019

Zrecenzowano: 31.07.2019

Przyjęto do druku: 31.07.2019 